\title{
Pain in Extremity
}

National Cancer Institute

\section{Source}

National Cancer Institute. Pain in Extremity. NCI Thesaurus. Code C78515.

Painful sensation in the upper or lower extremities. 